\title{
PENGARUH PENGGUNAAN PUPUK DI LAHAN PERTANIAN TERHADAP KUALITAS AIR PADA SALURAN TERSIER DI KAWASAN RASAU JAYA III
}

\author{
Lila Bila Renica ${ }^{1}$, Kartini ${ }^{2}$, Dian Rahayu Jati ${ }^{1}$ \\ ${ }^{1}$ Program Studi Teknik Lingkungan Jurusan Teknik Sipil Fakultas Teknik Universitas Tanjungpura, Pontianak \\ 2Program Studi Teknik Sipil Jurusan Teknik Sipil Fakultas Teknik Universitas Tanjungpura, Pontianak \\ Email: brenichlha@gmail.com
}

\begin{abstract}
ABSTRAK
Salah satu aktivitas yang dapat menyebabkan turunnya kualitas air permukaan adalah aktivitas pertanian. Lahan pertanian yang masih aktif digunakan oleh masyarakat salah satunya terdapat di Kabupaten Kubu Raya Kecamatan Rasau Jaya III. Daerah ini merupakan wilayah yang sebagian besar adalah lahan pertanian dan perkebunan sehingga dalam penggunaan pupuk sangatlah diperhatikan. Salah satu jenis pupuk yang banyak digunakan pada sektor pertanian adalah jenis pupuk NPK (NitrogenFosfor-Kalium). Seperti di daerah Rasau Jaya III, sebagian besar petani menggunakan jenis pupuk ini untuk menyuburkan lahan pertanian mereka khususnya tanaman padi. Penelitian ini bertujuan untuk mengetahui bagaimana kualitas air permukaan dan pengaruh jarak pengambilan sampel terhadap konsentrasi pupuk ditinjau dari parameter Nitrat Phosfat dan Kalium pada saluran tersier kawasan Rasau Jaya III. Sumber pupuk pada penelitian ini hanya berasal dari satu petak sawah saja, hal ini dikarenakan tidak tersedianya pupuk NPK untuk petani seperti periode tanam sebelumnya.

Metode yang digunakan dalam pengambilan sampel adalah grab sampling. Sampel diambil pada 10 titik sebelum dan setelah pemupukan di saluran tersier kawasan Rasau Jaya III. Pengambilan sampel setelah pemupukan dilakukan pada kondisi air yang sedang surut dan intensitas curah hujan yang rendah.

Hasil analisis pada ketiga parameter nitrat, phosfat dan kalium baik sebelum ataupun setelah pemupukan masih berada dibawah ambang batas baku mutu menurut PP RI No 82 Tahun 2001 dimana untuk parameter nitrat ambang batas baku mutu kelas IV adalah $20 \mathrm{mg} / \mathrm{l}$. Untuk parameter phosfat baku mutu kelas IV adalah $5 \mathrm{mg} / \mathrm{l}$. Parameter kalium tidak terdapat pada standar baku mutu menurut PP RI No 82 Tahun 2001. Nilai korelasi nitrat sebelum pemupukan adalah $-0,11$ dan setelah pemupukan adalah $-0,52$, kedua nilai tersebut dikategorikan tidak ada korelasi, karena nilai tersebut cenderung mendekati nilai 0 . Untuk nilai korelasi phosfat sebelum pemupukan adalah $-0,05$ dan phosfat setelah pemupukan adalah $-0,12$. Kedua nilai tersebut juga dikategorikan tidak ada korelasi. Untuk parameter kalium nilai korelasi ( $r$ ) nya tidak dapat dihitung karena nilai konsentrasi yang sama disetiap titik pengambilan sampelnya. Tidak adanya korelasi antara jarak pengambilan sampel terhadap konsentrasi yang didapat dikarenakan beberapa faktor yang mempengaruhi penelitian pada saat pengambilan sampel seperti sumber pupuk yang berasal hanya dari satu petak sawah saja dan juga intensitasi curah hujan yang cukup rendah.
\end{abstract}

Kata kunci : lahan pertanian, pupuk NPK, saluran tersier, kualitas air.

ABSTRACT
One of the activities that may cause degradation/decline of surface water quality is agricultural activity. Agricultural lands which still active are used by people who lived in Kubu Raya Regency especially in Sub district of Rasau Jaya III. This sub district is an area which mostly used for agricultural and plantation, that's way the use of fertilizers are considered. One of the fertilizer which often used in the agricultural sector is NPK (Nitrogen-Phosphorus-Potassium). Especially in Sub District of Rasau Jaya III, almost of the farmers use this fertilizer in order to fertilize their rice fields. This research has purposed in order to know how the water quality and the distance of sampling points have effect to fertilizer concentration in terms of Nitrate, Phosphate and Potassium parameter in tertiary channel of Sub District of Rasau Jaya III. The fertilizer in this study only comes from one rectangular land of rice fields, this is because the NPK fertilizers unavailable for the farmers just like the previous period.

The method that has been used in this research is grab sampling. The samples has been collected in 10 points/spots before and after fertilizing process in tertiary channel of Sub District of Rasau Jaya III. The sampling after fertilizing process has been conducted during low level of water and rainfall. 
The results before and after fertilizing process are still below the minimum standard according to PP RI No. 82 year of 2001 where the minimum standard of Nitrate parameter class IV is $20 \mathrm{mg} / \mathrm{l}$ and 5 $\mathrm{mg} / \mathrm{l}$ for Phosphate parameter. The parameter of potassium is not registered yet in PP RI No. 82 year of 2001. The value of Nitrate concentration before fertilizing process was $-0,11$ and $-0,52$ after fertilizing process, there is no correlation from both values, because those values have tendency to approach 0 value. The correlation of phosphate before fertilizing process was - 0,05 and - 0,12 after fertilizing process. Both of those values also don't have a correlation. The correlation of Potassium parameter couldn't be counted because the values are the same in every sampling points/spots. There is no correlation between the sampling distance with concentration which could caused by few factors during sampling period/time such as fertilizer which only came from one rectangular of rice fields and also rainfall intensity which was low.

Keywords : agricultural, NPK fertilizer, tertiary channel, water quality,

\section{PENDAHULUAN}

Salah satu aktivitas yang dapat menyebabkan turunnya kualitas air permukaan adalah aktivitas pertanian. Pencemaran yang diakibatkan oleh aktivitas pertanian ini disebabkan oleh sisa pemakaian pupuk buatan, pestisida, dan herbisida yang berlebihan. Banyak jenis pupuk yang digunakan pada kegiatan pertanian, salah satu jenis pupuk yang banyak digunakan pada sektor pertanian adalah jenis pupuk NPK (Nitrogen-Fosfor-Kalium). Seperti di daerah Rasau Jaya III, sebagian besar petani menggunakan jenis pupuk ini untuk menyuburkan lahan pertanian mereka khususnya tanaman padi. Untuk itu diperlukan penelitian untuk mengetahui sejauh mana pengaruh penggunaan pupuk pada aktivitas pertanian terhadap kualitas air di kawasan Rasau Jaya III.

\section{METODOLOGI PENELITIAN}

Lokasi penelitian berada di saluran tersier yang berada didekat lokasi pemupukan kawasan Rasau Jaya III.

\section{A. Pengumpulan Data}

Data sekunder yang digunakan antara lain berupa profil Kecamatan Rasau Jaya, data curah hujan harian dan data ramalan pasang surut Sungai Kapuas Kecil. Pengumpulan data primer dilakukan dengan melakukan pengukuran debit aliran, dimana untuk menghitung debit aliran dilakukan terlebih dahulu pengukuran penampang dan kecepatan aliran. Namun pada penelitian ini kecepatan aliran tidak dapat diukur karena tidak adanya gerakan arus aliran, sehingga debit aliran tidak dapat dihitung. Pengambilan sampel air dengan metode grab sample, dan pengujian kualitas air.

\section{B. Pengambilan Sampel}

Pengambilan sampel dilakukan pada 10 titik sampling dengan jarak 25 meter antara setiap titik sebelum dan setelah pemupukan. Namun, pada saat setelah pemupukan pengambilan sampel dilakukan dua kali dengan kondisi yang berbeda, dimana kondisi kedua dijadikan sebagai data bandingan. Kondisi pertama setelah pemupukan pengambilan sampel dilakukan pada saat kondisi air sedang surut dengan intensitas curah hujan yang kecil dan kondisi kedua dilakukan pada saat kondisi air sedang pasang dengan intensitas curah hujan cukup tinggi. Namun, pada kondisi kedua pengambilan sampel hanya dilakukan pada dua titik sampel, yaitu titik sampel 1 dan titik sampel 10.

\section{Analisis Hasil}

Analisis yang dilakukan meliputi analisis kualitas air pada saluran tersier kawasan Rasau Jaya III dengan melakukan uji terhadap parameter-parameter seperti Nitrogen dalam bentuk Nitrat $\left(\mathrm{NO}_{3}\right)$, Fosfor dalam bentuk Phosfat $\left(\mathrm{PO}_{4}\right)$ dan Kalium $(\mathrm{K})$. Hasil uji parameter parameter tersebut kemudian dibandingkan dengan baku mutu air sesuai Peraturan Pemerintah Republik Indonesia No. 82 Tahun 2001 tentang Pengelolaan Kualitas Air dan 
Pengendalian Pencemar Air kelas IV yang diperuntukkan untuk irigasi. Selain itu juga akan dikaji bagaimana pengaruh jarak terhadap konsentrasi parameter nitrat, phosfat dan kalium dengan mengunakan analisis regresi linear.

\section{HASIL DAN PEMBAHASAN}

\section{A. Data Hasil Penelitian Kualitas Air}

\section{a. Nitrat}

Grafik perbandingan konsentrasi nitrat sebelum dan setelah pemupukan dapat dilihat pada gambar dibawah ini (Hasil Analisis, 2014):

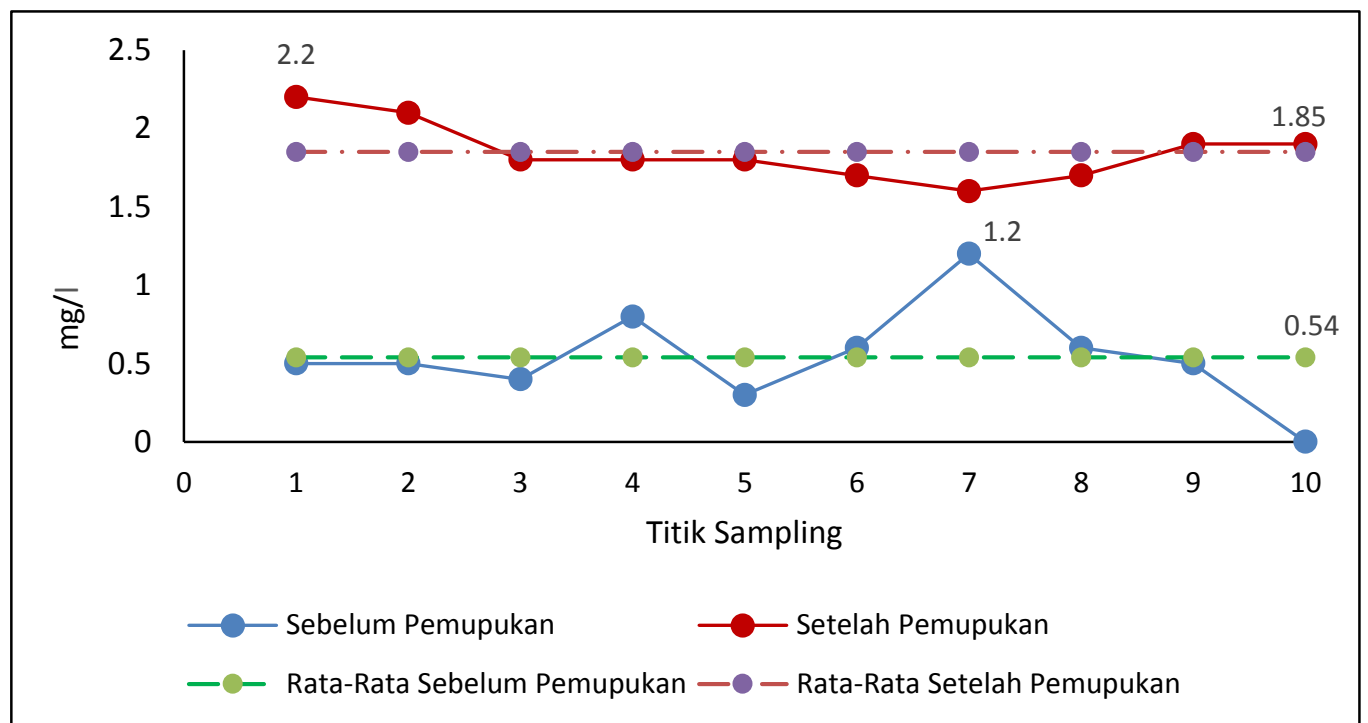

Gambar 1. Grafik Konsentrasi Nitrat

Gambar 1 menunjukkan konsentrasi nitrat pada saat sebelum pemupukan konsentrasi tertinggi berada pada titik sampel 7 dengan nilai konsentrasinya $1,2 \mathrm{mg} / \mathrm{l}$, dan setelah pemupukan konsentrasi tertingginya berada di titik sampel 1 dengan nilai konsentrasinya 2,2 $\mathrm{mg} / \mathrm{l}$. Konsentrasi nitrat baik sebelum dan setelah pemupukan masih berada dibawah ambang batas baku mutu kelas IV menurut Peraturan Pemerintah Republik Indonesia No. 82 Tahun 2001 tentang Pengelolaan Kualitas Air dan Pengendalian Pencemar Air, yaitu 20 mg/l. Nitrat $\left(\mathrm{NO}_{3}\right)$ adalah bentuk utama Nitrogen di perairan alami dan merupakan nutrien utama bagi pertumbuhan tanaman dan algae. Nitrat nitrogen sangat mudah larut dalam air dan bersifat stabil. Senyawa ini dihasilkan dari proses oksidasi sempurna senyawa nitrogen di perairan (Effendi, 2003). Pada perairan yang menerima limpasan air dari daerah pertanian yang banyak mengandung pupuk, kadar nitratnya dapat mencapai 1000 mg/l (Davis dan Cornwell, 1991), namun hasil analisis untuk kadar nitrat setelah pemupukan di kawasan pertanian Rasau Jaya III ini masih dibawah ambang batas (dari 10 titik sampel konsentrasi nitrat berkisar dari 1,6 - 2,2 $\mathrm{mg} / \mathrm{l})$. Banyak faktor yang mempengaruhi rendahnya nilai konsentrasi Nitrat ini, kurangnya penggunaan pupuk dan rendahnya intensitas curah hujan juga dapat mempengaruhi laju infiltrasi dari konsentrasi Nitrat, sehingga menyebabkan konsentrasi Nitrat hanya tertahan di tanah dan tidak mengalir ke saluran tersier.

\section{b. Phosfat}

Grafik perbandingan konsentrasi phosfat sebelum dan setelah pemupukan dapat dilihat pada gambar dibawah ini (Hasil Analisis, 2014) : 


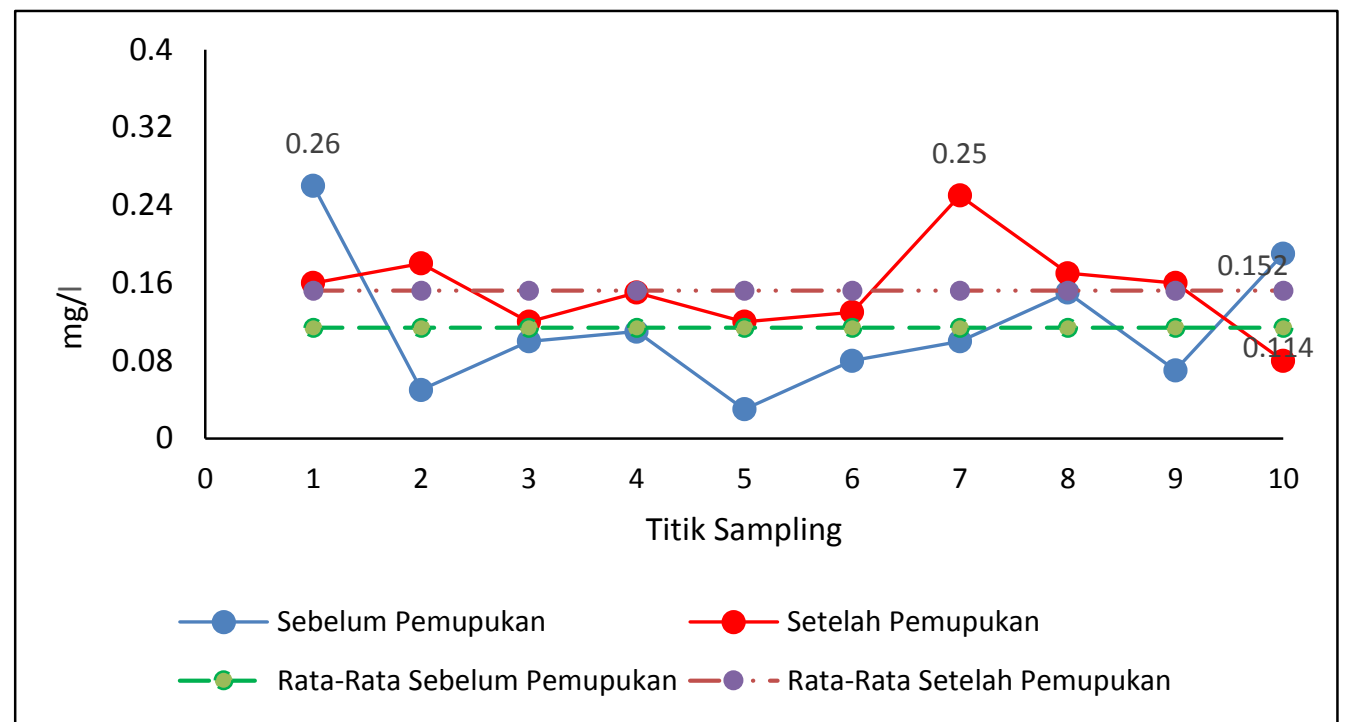

Gambar 2. Grafik Konsentrasi Phosfat

Konsentrasi phosfat pada gambar 2 diatas menunjukkan pada saat sebelum pemupukan konsentrasi tertinggi berada di titik sampel 1 yaitu $0,26 \mathrm{mg} / \mathrm{l}$ dan setelah pemupukan konsentrasi tertinggi berada di titik sampel 7 yaitu $0,25 \mathrm{mg} / \mathrm{l}$. Konsentrasi phosfat sebelum dan setelah pemupukan ini juga masih berada dibawah ambang batas baku mutu kellas IV menurut PP RI No. 82 Tahun 2001 yaitu 5 mg/l. Konsentrasi phosfat sebelum pemupukan nilai konsentrasinya lebih tinggi dibandingkan konsentrasi phosfat setelah pemupukan, hal ini disebabkan oleh beberapa kemungkinan, seperti kesalahan pengukuran pada saat pengambilan sampel, dan juga akibat dari pemupukan yang terjadi pada periode sebelumnya dimana pemupukan tersebut dilakukan pada semua petak sawah tidak seperti pada saat setelah pemupukan yang hanya dilakukan pada satu petak sawah saja, sehingga menyebabkan sisa kadar phosfat yang tidak terserap oleh padi akan tertimbun didalam tanah dan dibantu oleh hujan maka aliran phosfat tersebut akan mengalir ke saluran tersier, karena titik sampel 1 yang berada didekat pintu air kemungkinan untuk terjadinya pengenceran sangat kecil sehingga menyebabkan nilai konsentrasi pada titik sampel 1 ini cukup tinggi dibanding dengan titik-titik sampel lainnya.

\section{c. Kalium}

Grafik perbandingan konsentrasi phosfat sebelum dan setelah pemupukan dapat dilihat pada gambar dibawah ini (Hasil Analisis, 2014) :

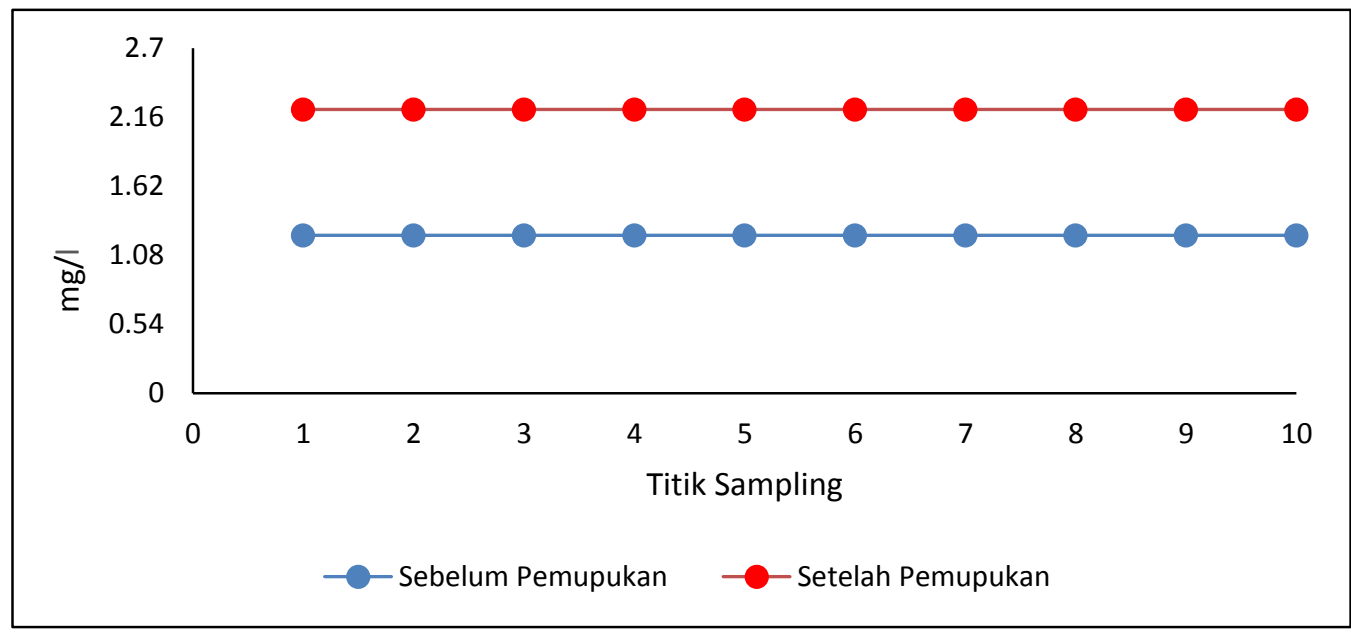

Gambar 3. Grafik Konsentrasi Kalium 
Konsentrasi Kalium pada saat sebelum maupun setelah pemupukan nilai konsentrasinya dari titik sampel 1 hingga titik sampel 10 nilainya sama yaitu 1,236 mg/l pada saat sebelum pemupukan dan 2,22 $\mathrm{mg} / \mathrm{l}$ pada saat setelah pemupukan. Untuk konsentrasi Kalium ini pada PP RI No 82 Tahun 2001 tidak tercantum berapa besar ambang batas baku mutunya, namun menurut McNeely (1979) kalium pada perairan tawar alami biasanya kurang dari $10 \mathrm{mg} / \mathrm{l}$ dan akan sangat berbahaya bagi sistem pencernaan dan saraf manusia apabila telah melebihi 2000 $\mathrm{mg} / \mathrm{l}$.

Nilai konsentrasi untuk ke tiga parameter yang diujikan yaitu nitrat, phosfat dan kalium baik sebelum maupun setelah pemupukan masih berada dibawah ambang batas baku mutu kelas IV. Faktor-faktor yang mempengaruhi hasil analisa kualitas air ini, diantaranya:

- Tidak serempaknya pemupukan di setiap petak sawah

- Tidak tersedianya pupuk NPK

- Rendahnya intensitas curah hujan setelah pemupukan

Dari faktor-faktor diatas, dilakukan kembali pengambilan sampel sebagai data bandingan dimana pengmbilan sampel kali ini dilakukan dengan kondisi yang berbeda dengan pengambilan sampel sebelumnya. Pada pengambilan sampel kali ini semua petak sawah dilakukan pemupukan oleh pupuk NPK dimana kondisi sawah pada saat itu tergenangi oleh air dengan kondisi air yang sedang pasang dan diikuti oleh curah hujan yang cukup tinggi. Hasil analisa dat kualitas air untuk pengambilan sampel kondisi kedua dapat dilihat pada tabel dibawah ini (Lab Fakultas Pertanian, Universitas Tanjungpura) :

Tabel 1. Data Kualitas Air

\begin{tabular}{|c|c|c|c|}
\hline \multirow{3}{*}{ Titik } & \multicolumn{3}{|c|}{ Parameter } \\
\cline { 2 - 4 } & Nitrat (NO $\left.\mathbf{O}_{3}\right)$ & Phosfat (PO & Kalium (K) \\
\cline { 2 - 4 } & $\mathbf{( m g / L )}$ & $\mathbf{( m g / L )}$ & $\mathbf{( m g / L )}$ \\
\hline 1 & 0,2 & 0,40 & 2,47 \\
\hline 10 & 0,0 & 0,52 & 1,24 \\
\hline
\end{tabular}

Konsentrasi nitrat pada titik sampel 1 adalah 0,2 mg/l, nilai ini jika dibandingkan dengan konsentrasi nitrat sebelumnya cenderung menurun dimana konsentrasi nitrat sebelumnya berkisar antara 1,6 - 2,2 mg/l. Menurut Triyono (2013) tanaman padi mempunyai kapasitas untuk menyerap unsur $\mathrm{N}$ dalam jumlah yang terbatas, sehingga $\mathrm{N}$ yang yang tidak diserap oleh tanaman padi akan mengalami proses volatilisasi, dan leaching. Akumulasi nitrat dalam lapisan tanah yang relatif tinggi yang mempunyai potensi terjadinya leaching menyebabkan konsentrasi nitrat bergerak ke lapisan tanah yang lebih dalam dan mencapai permukaan air tanah. Aplikasi irigasi dengan penggenangan petak sawah akan mempercepat proses leaching dengan melarutkan nitrat yang terdapat pada lapisan tanah dan melarutkan nitrat yang terdapat pada permukaan tanah yang menyebabkan peningkatan konsentrasi nitrat pada air permukaan. Namun nilai konsentrasi pada pengambilan sampel kali ini cenderung menurun dari konsentrasi sebelumnya. Faktor curah hujan yang cukup tinggi menyebabkan konsentrasi Nitrat tersebut terencerkan sehingga konsentrasi yang didapatpun cukup rendah.

Konsentrasi Phosfat seperti pada tabel 1 diatas menunjukkan dititik sampel 1 nilai konsentrasinya adalah $0,4 \mathrm{mg} / \mathrm{l}$ dan di titik 10 nilai konsentrasinya adalah $0,52 \mathrm{mg} / \mathrm{l}$. Nilai ini cukup meningkat jika dibandingkan dengan konsentrasi phosfat sebelumnya. Phosfat bersifat tidak mobile didalam tanah sehingga efisiensinya sangat rendah (Anwar,1996). Hanya 10\% dari pupuk phosfat yang diserap oleh tanaman padi, kondisi ini menyebabkan terjadinya penimbunan phosfat yang sangat tinggi pada tanah (Thaher,1996). Akibat rendahnya phosfat yang diserap oleh padi dan dibantu oleh curah hujan yang cukup tinggi serta kondisi sawah yang tergenangi menyebabkan phosfat tersebut akan terserap kedalam tanah (infiltrasi) dan 
ketika tingkat kelembaban tanah tersebut telah cukup jenuh air hujan yang baru masuk kedalam tanah agak bergerak secara lateral (horizontal) untuk selanjutnya pada tempat tertentu akan keluar lagi ke permukaan tanah dan akhirnya mengalir ke saluran tersier. Meskipun demikian, konsentrasi phosfat ini masih berada dibawah ambang batas buku mutu kelas IV yaitu $5 \mathrm{mg} / \mathrm{l}$.

Konsentrasi kalium pada tabel 1 diatas menunjukkan perbedaan dari konsentrasi kalium sebelumnya dimana konsentrasi kalium sebelumnya disemua titik pengambilan sampel nilai konsentrasi kalium cenderung sama. Namun pada pengambilan sampel kali ini konsentrasi yang didapat antara titik sampel 1 dan titik sampel 10 nilainya berbeda. Hasil yang didapat untuk parameter kalium dititik pertama nilai kaliumnya adalah $2,47 \mathrm{mg} / \mathrm{l}$ dan pada titik sepuluh nilainya $1,24 \mathrm{mg} / \mathrm{l}$. Nilai ini menunjukkan adanya perbedaan dengan hasil tes yang pertama dimana nilai kalium disemua titik sama. Kalium dalam tanah sering ditemui sebagai faktor pembatas, karena $\mathrm{K}$ merupakan unsur hara yang mobile dan sangat peka terhadap pencucian, terutama di daerah tropik dengan curah hujan yang tinggi (Soepardi, 1985). Karena sifat kalium yang mobile dan mudah tercuci ini menyebabkan nilai kalium yang kurang lebih sama dengan hasil sebelumnya walaupun dengan kondsi yang berbeda.

\section{B. Analisis Pengaruh Jarak Pengambilan Sampel Terhadap Konsentrasi}

Jarak pengambilan sampel pada saluran tersier ini adalah 25 meter antar setiap titiknya hingga ke jarak 225 meter. Sumber pupuk hanya berasal dari 1 petak sawah yaitu petak ke dua terhitung dari pintu air dan berada disekitar 25-50 meter jarak pengambilan sampel. Berikut akan dibahas pengaruh jarak pengambilan sampel terhadap konsentrasi yang didapat dari masing-masing parameter.

\section{a. Nitrat}

Grafik regresi linear nitrat dapat dilihat pada gambar dibawah ini (Hasil Analisis, 2014)

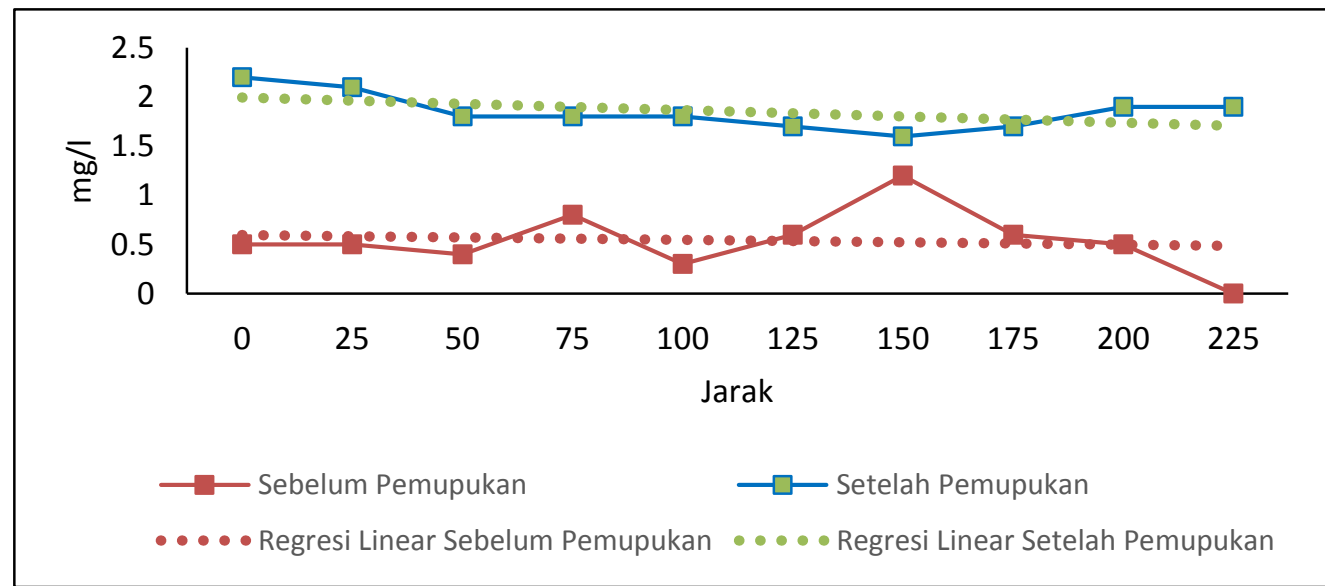

Gambar 4. Grafik Regresi Linear Nitrat

Dari grafik pada gambar 4 dapat dilihat garis linear pada saat sebelum dan setelah pemupukan. Penarikan garis regresi linear pada data diatas dimaksudkan untuk membuat besarnya nilai penyimpangan (deviasi) antara titik-titik pengamatan yang dikaji dan garis regresi tersebut sekecil mungkin. Dari garis regresi tersebut, baik sebelum ataupun setelah pemupukan konsentrasi nitrat dari jarak 0 hingga ke jarak 225 meter cenderung menurun. Contoh perhitungan persamaan garis regresi dan data yang diperlukan untuk menghitung nilai $r^{2}$ pada parameter nitrat sebelum dan setelah pemupukan dapat dilihat berikut ini: 
Tabel 2. Perhitungan Persamaan Garis Regresi Nitrat Sebelum Pemupukan

\begin{tabular}{|c|c|c|c|c|}
\hline $\mathbf{n}$ & $\begin{array}{c}\mathbf{x} \\
\text { (Jarak) }\end{array}$ & $\begin{array}{c}\mathbf{y} \\
\text { (Konsentrasi) }\end{array}$ & $\mathbf{x . y}$ & $\mathbf{x}^{\mathbf{2}}$ \\
\hline 1 & 0 & 0,5 & 0 & 0 \\
\hline 2 & 25 & 0,5 & 12,5 & 625 \\
\hline 3 & 50 & 0,4 & 20 & 2500 \\
\hline 4 & 75 & 0,8 & 60 & 5625 \\
\hline 5 & 100 & 0,3 & 30 & 10000 \\
\hline 6 & 125 & 0,6 & 75 & 15625 \\
\hline 7 & 150 & 1,2 & 180 & 22500 \\
\hline 8 & 175 & 0,6 & 105 & 30625 \\
\hline 9 & 200 & 0,5 & 100 & 40000 \\
\hline 10 & 225 & 0 & 0 & 50625 \\
\hline$\Sigma$ & 1125 & 5,4 & 582,5 & 178125 \\
\hline
\end{tabular}

Dari data pada tabel 2 dapat dihitung koefisien a dan b untuk persamaan regresi sederhana dengan menggunakan rumus seperti dibawah ini:

$$
\begin{aligned}
\mathrm{a} & =\frac{\left(\sum y\right)\left(\sum x\right)^{2}-\left(\sum x\right)\left(\sum x y\right)}{n \sum x^{2}-\left(\sum x\right)^{2}} \\
& =\frac{(5,4)(178125)-(1125)(582,5)}{10(178125)-(1125)^{2}}=\frac{961875-655312,5}{1781250-1265625}=\frac{306562,5}{515625}=\mathbf{0 , 5 9 4 5} \\
\mathrm{b} & =\frac{n \sum x y-\left(\sum x\right)\left(\sum y\right)}{n \sum x^{2}-\left(\sum x\right)^{2}} \\
& =\frac{(10)(582,5)-(1125)(5,4)}{10(178125)-(1125)^{2}}=\frac{5825-6075}{1781250-1265625}=\frac{-250}{515625}=-\mathbf{0 , 0 0 0 4 8}
\end{aligned}
$$

Sehingga persamaan regresinya adalah : $y=0,5945-0,00048 x$

\begin{tabular}{|c|c|c|c|c|c|c|c|}
\hline $\mathrm{n}$ & $\begin{array}{c}\mathbf{x}_{\mathbf{i}} \\
\text { (Jarak) }\end{array}$ & $\begin{array}{c}\mathbf{y}_{i} \\
\text { (Konsentrasi) }\end{array}$ & $\mathbf{x}_{i} \cdot \mathbf{y}_{\mathrm{i}}$ & $x_{i}^{2}$ & $\widehat{\boldsymbol{y}}_{\boldsymbol{i}}$ & $\left(\widehat{y}_{i}-\bar{y}\right)^{2}$ & $\left(y_{i}-\bar{y}\right)^{2}$ \\
\hline 1 & 0 & 0,5 & 0 & 0 & 0,5945 & 0,00298 & 0,0016 \\
\hline 2 & 25 & 0,5 & 12,5 & 625 & 0,5824 & 0,00180 & 0,0016 \\
\hline 3 & 50 & 0,4 & 20 & 2500 & 0,5703 & 0,00092 & 0,0196 \\
\hline 4 & 75 & 0,8 & 60 & 5625 & 0,5582 & 0,00033 & 0,0676 \\
\hline 5 & 100 & 0,3 & 30 & 10000 & 0,5461 & 0,000037 & 0,0576 \\
\hline 6 & 125 & 0,6 & 75 & 15625 & 0,5339 & 0,000037 & 0,0036 \\
\hline 7 & 150 & 1,2 & 180 & 22500 & 0,5218 & 0,00033 & 0,4356 \\
\hline 8 & 175 & 0,6 & 105 & 30625 & 0,5097 & 0,00092 & 0,0036 \\
\hline 9 & 200 & 0,5 & 100 & 40000 & 0,4976 & 0,00180 & 0,0016 \\
\hline 10 & 225 & 0 & 0 & 50625 & 0,4855 & 0,00298 & 0,2916 \\
\hline$\Sigma$ & 1125 & 5,4 & 582.5 & 178125 & 5,4 & 0,01212 & 0,884 \\
\hline Rata-rata & & 0,54 & & & & & \\
\hline
\end{tabular}

Setelah didapat persamaan regresinya, kemudian akan dihitung besarnya nilai $\mathrm{r}^{2}$ atau koefisien determinasi seperti dibawah ini:

Tabel 2. Perhitungan Regresi Nitrat Sebelum Pemupukan 


$$
\begin{aligned}
\beta_{1} & =\frac{n \sum_{i=1}^{n} x_{i . y_{i}}-\left(\sum_{i=1}^{n} x_{i}\right)\left(\sum_{i=1}^{n} y_{i}\right)}{n \sum_{i=1}^{n} x_{i}{ }^{2}-\sum_{i=1}^{n}\left(x_{i}\right)^{2}} \\
\beta_{1} & =\frac{(10 \times 582,5)-(1125 \times 5,4)}{(10 \times 178125)-(1125)^{2}}=\frac{5825-6075}{1781250-1265625}=\frac{-250}{515625}=\mathbf{- 0 , 0 0 0 4 8} \\
\beta_{0} & =\frac{1}{n} \sum_{i=1}^{n} y_{i}-\beta_{1} \frac{1}{n} \sum_{i=1}^{n} x_{i} \\
\beta_{0} & =\frac{1}{10} \times 5,4-(-0,000484848)\left(\frac{1}{10} \times 1125\right) \\
& =\frac{5,4}{10}-(-0,000484848)\left(\frac{1125}{10}\right) \\
& =\mathbf{0 , 5 9 4 5 4 5} \\
\mathrm{r}^{2} & =\frac{\sum_{i=1}^{n}\left(\tilde{y}_{i-} \bar{y}\right)^{2}}{\sum_{i=1}^{n}\left(y_{i-} \bar{y}\right)^{2}} \mathrm{r}^{2}=\frac{0,1212}{0,884}=\mathbf{0 , 0 1 3 7}
\end{aligned}
$$

Dari hasil perhitungan nilai $r^{2}$ yang didapat pada nitrat sebelum pemupukan adalah 0,0137 hal ini berarti hanya $1,37 \%$ variasi yang terdapat dalam variabel y (konsentrasi nitrat) yang berkaitan dengan pengaruh variabel $x$ (jarak). Dengan nilai $r^{2}$ nitrat pada sebelum pemupukan yang didapat lebih mendekati pada nilai 0 sehingga tidak ada yang bisa dijelaskan oleh model regresi yang diajukan.

Setelah mendapatkan nilai $r^{2}$, selanjutnya dilakukan perhitungan korelasi guna mengetahui seberapa kuatnya korelasi linear yang terjadi antara jarak pengambilan sampel terhadap konsentrasi. Data yang diperlukan untuk menghitung korelasi sebelum pemupukan untuk parameter nitrat dapat dilihat pada tabel dibawah ini :

Tabel 3. Perhitungan Korelasi Nitrat Sebelum Pemupukan

\begin{tabular}{|c|c|c|c|c|c|}
\hline $\mathbf{n}$ & $\begin{array}{c}\mathbf{x}_{\mathbf{i}} \\
\text { (Jarak) }\end{array}$ & $\begin{array}{c}\mathbf{y}_{\mathbf{i}} \\
\text { (Konsentrasi) }\end{array}$ & $\mathbf{x}_{\mathbf{i} \cdot \mathbf{y}_{\mathbf{i}}}$ & $\mathbf{x}_{\mathbf{i}}{ }^{2}$ & $\mathbf{y}_{\mathbf{i}}{ }^{2}$ \\
\hline 1 & 0 & 0,5 & 0 & 0 & 0,25 \\
\hline 2 & 25 & 0,5 & 12,5 & 625 & 0,25 \\
\hline 3 & 50 & 0,4 & 20 & 2500 & 0,16 \\
\hline 4 & 75 & 0,8 & 60 & 5625 & 0,64 \\
\hline 5 & 100 & 0,3 & 30 & 10000 & 0,09 \\
\hline 6 & 125 & 0,6 & 75 & 15625 & 0,36 \\
\hline 7 & 150 & 1,2 & 180 & 22500 & 1,44 \\
\hline 8 & 175 & 0,6 & 105 & 30625 & 0,36 \\
\hline 9 & 200 & 0,5 & 100 & 40000 & 0,25 \\
\hline 10 & 225 & 0 & 0 & 50625 & 0 \\
\hline$\Sigma$ & 1125 & 5,4 & 582,5 & 178125 & 3,8 \\
\hline
\end{tabular}

Dari data tabel 3 diatas dapat dihitung nilai korelasi $(r)$ dengan menggunakan rumus seperti dibawah ini:

$$
\begin{aligned}
& r=\frac{\sum\left(x_{i} y_{i)}-\left\{\left(\sum x_{i}\right)\left(\sum y_{i}\right)\right\} / n\right.}{\left.\left.\sqrt{\left[\sum x_{i}^{2}-\left\{\left(\sum x_{i}\right)^{2}\right.\right.}\right\} / n\right]\left[\sum y_{i}^{2}-\left\{\left(\sum y_{i}\right)^{2}\right\} / n\right]}=\frac{582,5-\{(1125)(5,4)\} / 10}{\left.\sqrt{[178125}-\left\{\left(1125^{2}\right)\right\} / 10\right]\left[3,8-\left\{(5,4)^{2}\right\} / 10\right]} \\
& =-\mathbf{0}, \mathbf{1 1}
\end{aligned}
$$


Nilai $r$ yang didapat adalah $-0,11$, hal ini menunjukkan bahwa jarak pengambilan sampel tidak berkorelasi terhadap konsentrasi nitrat yang didapat karena nilai $r$ yang cenderung lebih mendekati nilai 0 .

Untuk parameter nitrat setelah pemupukan dan phosfat sebelum maupun setelah pemupukan hasil persamaan regresi, nilai $r^{2}$ dan nilai $r$ (korelasi) nya dapat dilihat pada tabel dibawah ini :

Tabel 4. Rekapitulasi Hasil Perhitungan Korelasi

\begin{tabular}{|l|c|c|c|}
\hline & $\begin{array}{c}\text { Nitrat Setelah } \\
\text { Pemupukan }\end{array}$ & $\begin{array}{c}\text { Phosfat Sebelum } \\
\text { Pemupukan }\end{array}$ & $\begin{array}{c}\text { Phosfat Setelah } \\
\text { Pemupukan }\end{array}$ \\
\hline Persamaan Regresi $(\mathrm{y})$ & $\mathrm{y}=1,99-0,0012 \mathrm{X}$ & $\mathrm{y}=0,12-0,00053 \mathrm{X}$ & $\mathrm{y}=0,16-0,000072 \mathrm{X}$ \\
\hline Koefisien Determinasi $\left(\mathrm{r}^{2}\right)$ & 0,279 & 0,0034 & 0,0014 \\
\hline Korelasi $(\mathrm{r})$ & $-0,52$ & $-0,05$ & $-0,12$ \\
\hline
\end{tabular}

Nilai korelasi ( $r$ ) untuk parameter nitrat dan phosfat baik sebelum dan setelah pemupukan nilai korelasinya adalah negatif, hal ini menunjukkan besarnya variabel y (konsentrasi nitrat) menurun ketika angka variabel $\mathrm{x}$ (jarak) bertambah besar dan dari kedua parameter ini menunjukkan antara jarak pengambilan sampel terhadap konsentrasi yang didapat berkorelasi lemah atau bahkan tidak berkorelasi karena nilai korelasi yang cenderung mendekati nilai 0 . Sebagai aturan umum dapat ditentukan bahwa korelasi antara dua variabel adalah lemah apabila $0 \leq|r| \leq 0,5$ dan mempunyai korelasi kuat apabila 0,8 $\leq|r| \leq 1$ (Gordon et al, 1992).

\section{b. Kalium}

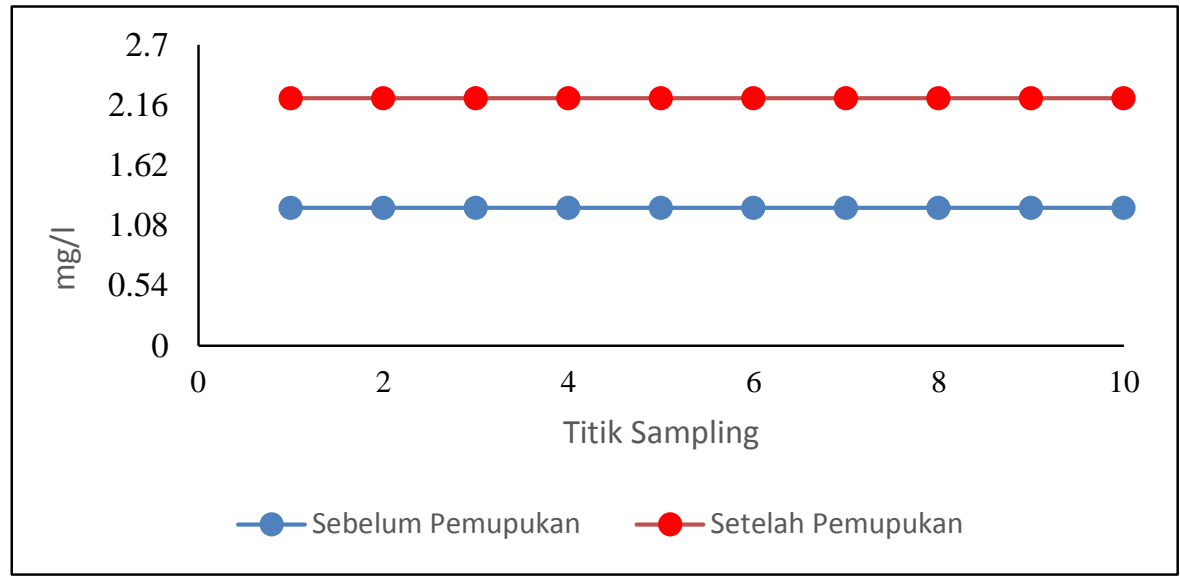

Gambar 4. Grafik Regresi Linear Kalium

Untuk parameter kalium, karena nilai konsentrasinya yang sama disetiap titiknya seperti pada gambar 5.18 baik sebelum maupun setelah pemupukan sehingga tidak dapat dihitung nilai $r^{2}$ dan nilai $r$ nya.

\section{KESIMPULAN}

Dari hasil penelitian yang telah dilakukan dapat ditarik kesimpulan sebagai berikut :

1. Dari hasil analisis pada parameter nitrat, phosfat dan kalium nilai konsentrasi dari ke tiga parameter ini masih berada dibawah ambang batas baku mutu kelas IV menurut PP RI 
No.82 Tahun 2001. Untuk parameter nitrat konsentrasi tertinggi terjadi pada saat setelah pemukan dimana konsentrasi tertinggi berada dititik sampel 1 yaitu 2,2 mg/l. Untuk parameter phosfat konsentrasi tertinggi terjadi setelah pemupukan dengan konsentrasi tertingginya berada dititik sampel 7 yaitu $0,25 \mathrm{mg} / \mathrm{l}$. Untuk parameter kalium nilai konsentrasinya sama di setiap titik sampel dimana pada sebelum pemupukan nilainya adalah $1,2 \mathrm{mg} / \mathrm{l}$ dan setelah pemupukan adalah $2,2 \mathrm{mg} / \mathrm{l}$. Nilai konsentrasi yang masih berada dibawah ambang batas baku mutu ini disebabkan oleh beberapa faktor seperti sumber pupuk NPK hanya berasal dari satu petak sawah dan juga rendahnya curah hujan yang terjadi setelah pemupukan.

2. Nilai korelasi nitrat sebelum pemupukan adalah $-0,1171$ dan setelah pemupukan adalah $-0,5282$, kedua nilai tersebut dikategorikan berkorelasi lemah atau bahkan tidak ada korelasi, karena nilai tersebut cenderung mendekati nilai 0. Sehingga dapat disimpulkan jarak pengambilan sampel tidak memberikan pengaruh terhadap konsentrasi yang didapat.

Untuk nilai korelasi phosfat sebelum pemupukan adalah -0,059 dan phosfat setelah pemupukan adalah $-0,121$. Kedua nilai ini juga dikategorikan berkorelasi lemah atau bahkan tidak ada korelasi. Dan untuk parameter kalium tidak dapat dihitung nilai $r$ nya, ini dikarenakan nilai konsentrasi kalium yang sama disetiap titik pengambilan sampelnya.

\section{Ucapan Terima Kasih}

Saya ingin mengucapkan terima kasih kepada Tuhan Yang Maha Esa atas berkat dan rahmatNya juga kepada keluarga yang telah banyak memberikan dukungan. Tidak lupa pula saya mengucapkan terima kasih kepada kedua pembimbing saya, Ibu Dr. Ir. Hj. Kartini, M.T dan Ibu Dian Rahayu Jati, S.T., M.Si serta Bapak Ir. H. Nasrullah CH, M.T. dan Bapak H. Kiki Prio Utomo, S.T., M.Sc. selaku dosen penguji saya yang telah banyak membantu dalam penelitian ini. Saya juga mengucapkan terima kasih kepada karyawan BMKG Pontianak, para petani di lokasi penelitian, teman - teman dan semua pihak yang telah banyak membantu saya yang tidak dapat saya sebutkan.

\section{Referensi}

Anwar, K. dan Nurita. 1997. Respon tanaman Padi dan Kedelai Terhadap Pemupukan Fosfat dan Residunya di Lahan Pasang Surut Sulfat Masam Tipe B dan C. Laporan Hasil Penelitian TA 1997/1998. Balittra. Banjarbaru.

Davis, M.L. dan Cornwell, D.A. 1991. Introduction to Environmental Engineering. Secon Edition. Mc-Graw-Hill, Inc., New York. 822 p.

Effendi, Hefni. 2003. Telaah Kualitas Air. Penerbit : Kanisius. Yogyakarta

Gordon, N.D., T.A.McMahon, dan B.L.Finlayson. 1992. Stream Hydrology. An Introduction for Ecologists. John Wiley \& Sons, New York. 526 hal.

McNeely, R,N., Nelmanis, V.P., dan Dawyer, L. 1979. Water Quality Source Book, A Guide to Water Quality Parameter. Inland Waters Directorate, Water Quality Branch, Ottawa, Canada. $89 \mathrm{p}$.

Pemerintah Republik Indonesia. 2001. Peraturan Pemerintah Nomor 82 Tahun 2001 tentang Pengelolaan Kualitas Air dan Pengendalian Pencemaran Air.

Soepardi.1985. Menuju Pemupukan Berimbang Guna Meningkatkan Jumlah dan Mutu Hasil Pertanian. Direktorat Penyuluhan Tanaman Pangan. Deptan. Jakarta.

Triyono, A., Purwanto, dan Budiyono. 2013. Efisiensi Penggunaan Pupuk N Untuk Pengurangan Kehilangan Nitrat pada Lahan Pertanian. Universitas Diponegoro. Semarang. 